\title{
Acacia Decurrens (Wild) an Invasive South Africa Tree: Chemical Profile, Antibacterial and Antioxidant Activities
}

\author{
Okoli Bamidele*, Molefe Nnana, Ledwaba Imelda and Modise Sekomeng \\ Institute of Chemical and Biotechnology, Vaal University of Technology, South Africa
}

Submission: August 29, 2017; Published: September 07, 2017

*Corresponding author: Joseph Bamidele Okoli, Institute of Chemical and Biotechnology Vaal University of Technology, South Africa,

Tel: +27767619418; Email: okolibj@binghamuni.edu.ng

\begin{abstract}
The present study describes the profile, antimicrobial and antioxidant potential of the stem bark of Acacia decurrens. The methanol and hexane fractions had $20 \%$ and $0.2 \%$ extract yield respectively. The GC-MS result of the hexane, chloroform, and ethyl acetate fractions confirm the presence of 52 compounds and the ICP analysis of the stem bark was found to contain high levels of $\mathrm{Co}, \mathrm{Zn}, \mathrm{Mn}, \mathrm{Ca}, \mathrm{Ni}, \mathrm{Mg}, \mathrm{Cr}, \mathrm{K}$ and Fe; which is an indication of hyper accumulation capacity. The UV-Visible spectra of showed various peaks which are indication of important radical scavenging Chromophores. Phytochemical screening indicated that the alkaloid (0.6-3.3\%) and saponins (5.1-8.6\%) contents of the various fractions were significantly lower than the tannin (30.9-55.8 mg TAE/g), steroid (13.92-41.2\%), phenol (40.6-65.5 mg GAE/g) and flavonoids (210.2-284.9 mg RUE/g) contents. The disk and well diffusion methods were used to determine the sensitivity and MIC of the fractions. The ethyl acetate and methanol were the most potent antibacterial fractions with $75 \%$ and $65 \%$ inhibition respectively with MIC of $12.5 \mu \mathrm{g} / \mathrm{ml}$ compared with ampicillin. The antioxidant activity of the fractions was analysed by different methods and revealed good antioxidant potential with different IC ${ }_{50}$ values of $42.2-49.6 \mathrm{mg} / \mathrm{mL}$ for ABTS and 37.8-75.0 $\mu \mathrm{g} / \mathrm{ml}$ for DPPH respectively, compared to standard antioxidants.
\end{abstract}

Keywords: A. decurrens; antioxidant; antibacterial; DPPH; ABTS; ICP-OES; GC-MS, UV/visible

Abbreviations: TC: Tannin Content; TFC: The Total Flavonoids; ZI: Zones Of Inhibition; MHB: Muller-Hinton Broth Medium

\section{Introduction}

Acacia decurrens (Willd), commonly known as black wattle or early green wattle is a perennial tree or shrub, in the subfamily Mimosoideae of the pea family Fabaceae. They are present in all terrestrial habitats, including alpine settings, rainforests, woodlands, grasslands, coastal dunes and deserts [1] and due to their prolific nature; they are being classified as invasive in some countries. The Acacia is repeatedly mentioned in the Book of Exodus, perhaps referring to Acacia raddiana, in regards to the construction of the Tabernacle [2]. The edible flowers and seed pods are used to produce dyes, while the trees are grown for firewood, fast-growing windbreak or shelter tree [3] and the edible gum from the trunk of the is used as a low-quality Arabic gum. In South Africa, Acacia decurrens is classified as an invasive species [4], threatening native wildlife [5]. Native wildlife may not have evolved defenses against the invader or they cannot compete with a species that has no predators and these can be exploited for its pharmacological potentials (such as anti- proliferative, antimicrobial and antioxidant activities) against native infections.

In this study, a preliminary investigation into the chemical composition, antimicrobial and antioxidant potential of $A$. decurrens will be conducted, for the first time. Major chronic and degenerative diseases such as atherosclerosis, ischemic heart disease, ageing, diabetes mellitus, cancer, immunosuppression, neurodegenerative diseases are caused by oxidative stress [6] and are one of the most important routes for producing free radicals in foods, drugs and even in living systems [7]. Antioxidative defense mechanisms have proven over time to be the most effective method of combating oxidative stress caused by free radicals. Recently, there has been an upsurge of interest in the pharmacological potentials of plants as antioxidants in reducing oxidative stress-induced tissue injury [8-9]. This research is focused on the generic protocol using a bioassayguided approach based on straight forward testing of the plant fractions followed by in vitro biological activity testing. 


\section{Materials and Methods}

\section{Chemicals}

Ethanol, methanol, hexane, ethyl acetate, chloroform, DMSO, ampicillin, nutrient broth sodium hydrogen carbonate, gallic acid, rutin hydrate, 2,2-dyphenyl-1-picrylhydrazyl (DPPH), 2,2'-azinobis(3-ethylbenzothia-zoline-6-sulfonic acid) (ABTS), potassiาum persulfate (di-potassium peroxdisulfate), potassium persul $\neg$ fate, Folin-Ciocalteu's phenol reagent, ascorbic acid, aluminium chloride were obtained from Sigma-Aldrich Chemicals Co., St Louis, MO, USA. All reagents used in this study are of analytical grade.

\section{Equipment}

The equipment employed in this study includes Spectroquant ${ }^{\circledR}$ Prove Spectrophotometer 100, Clarus 500 Perkin Elmer (Auto system XL) Gas Chromatograph coupled to a mass Spectrophotometer detector and PerkinElmer Elan DRC II inductively coupled plasma mass spectrometer.

\section{Plant Materials}

The fresh stem bark of $A$. decurrens was harvested around October 2016 near Vaal Dam Road, Heidelberg (26.5033॰S, 28.4397 $\circ$ E), and South Africa, diced, and dried at an ambient temperature at a relatively low humidity. Authentication of the of $A$. decurrens stem bark was carried out by the South Africa National Biodiversity Institute, Pretoria, and voucher specimen number: 1200-1, and was deposited at Pretoria National Botanical Garden. The extraction was performed by serial maceration using $4 \mathrm{~L}$ of each solvent: hexane, chloroform, ethyl acetate, and methanol with slight agitation at $111 \mathrm{revs} / \mathrm{min}$ for seven days. The solvents were removed.

\section{Extraction and Determination of plant yield}

The A. decurrens was diced to facilitate drying at a relative humidity of $55 \%$ at ambient temperature and the dried stem barks were pulverized using a hammer mill. The powder was stored in polyethene bags to prevent moisture absorption and contamination. Exactly $2 \mathrm{~kg}$ of the powdered stem bark were macerated at ambient temperature in $4 \mathrm{~L}$ of hexane, chloroform, ethyl acetate and methanol sequentially for seven days each with slight agitation at $111 \mathrm{revs} / \mathrm{min}$. Afterwards, the extracts were filtered through Whatman filter paper No. $42(125 \mathrm{~mm})$ then through cotton wool and dried to constant weight in open air.

\section{Qualitative Phytochemical Screening}

The Phytochemical screening of the fractions was carried out using standard qualitative procedures [10].

\section{Quantitative Phytochemical Screening}

The Total Phenolic Content (TPC) was determined as described by Vuong, Hirun, Roach, Bowyer, Phillips, Scarlett [11], the results were expressed as mg of gallic acid equivalents per $g$ of sample (mg GAE/g). The Total Flavonoids (TFC) was measured as described by Zhishen, Mengcheng, Jianming [12], the results were expressed as mg of rutin equivalents per $\mathrm{g}$ of sample (mg RUE/g). The Tannin Content (TC) was determined as described by Rajeev, Pawan, Gagandeep [13], and the results were expressed as $\mathrm{mg}$ of tannin equivalents per $\mathrm{g}$ of sample (mg TAE/g). The alkaloid content was determined as described by Fazel, Hamidreza, Rouhollah, Mohammadreza [14], saponins content determined by the method of Makkar, Siddhuraju, Becker [15] and the terpenoids content Ferguson [16] and expressed as percentage respectively.

\section{Elemental Analysis}

Aqua regia digestion $\left(\mathrm{HCl}-\mathrm{HNO}_{3}\right)$ : $\mathrm{A}$ mixture of concentrated $\mathrm{HCl}$ and $\mathrm{HNO}_{3}$, in the ratio of 3:1 is used as the aqua regia mixture. According to Muinde, Nguu, Ogoyi, Shiundu [17], $1.0 \mathrm{~g}$ of diced stem bark was digested in $10 \mathrm{ml}$ of aqua regia mixture in digestion tubes for $3 \mathrm{hrs}$ at $60{ }^{\circ} \mathrm{C}$. After cooling the entire digest were filtered and transferred into $50 \mathrm{ml}$ standard volumetric flask with deionized water. Reagent blanks were prepared similarly to the samples. All sample solution was clear and diluted 10 times before analysis.

ICP-OES measurement: The measurement was calibrated by the method of external standards with $\mathrm{Rh}, \mathrm{Re}$ as the internal standard. The reagent blank solution contained $1 \%$ of concentrated $\mathrm{HNO}_{3}$. Mixed standard solutions containing 7 elements, $\mathrm{Cr}, \mathrm{Ni}, \mathrm{Zn}, \mathrm{Fe}, \mathrm{Co}, \mathrm{K}$ and $\mathrm{Ca}$ were prepared in reagent blank solutions [18].

\section{Spectroscopic Analysis}

\section{UV-Visible Spectroscopic Analysis Of The Fractions}

The fractions of $A$. decurrens were analysed in the UVVisible range between 200-900 nm using PerkinElmer Spectrophotometer and the characteristic peaks were recorded.

\section{GC - MS analysisof the fractions}

The analysis was carried out on Clarus 500 PerkinElmer Gas Chromatograph with an Elite -5 (100\% Dimethylpolysiloxane) column coupled to a mass spectrometer detector. The GC-MS method used in the study involves setting the column at an initial temperature of $110 \mathrm{oC}$ and held for $2 \mathrm{~min}$. After 2 mins the oven temperature has raised the rate of $5 \mathrm{oC} / \mathrm{min}$, to $280 \mathrm{oC}$, and held for $9 \mathrm{~min}$. The carrier gas (He) flow rate was maintained $1 \mathrm{ml} /$ min while the injection port temperature was kept at $250 \mathrm{oC}$. The solutions of the fractions were injected in split mode as 10:1. Mass spectral scan range was set at 45-450 (m/z).

\section{Antimicrobial Assay \\ Preparation of Inoculum}

The test organism Micrococcus luteus (ATCC 26883) Staphylococcus aureus (ATCC 25923), Escherichia coli (NCTC 11954), Salmonella typhi (ATCC 29692), Klebsiella pneumonia (BAA 1706), Shigella sonnei (ATCC 25931), Staphylococcus epidermis (ATCC 12228), Listeria monocytogenes (ATCC(R) BAA751TM) and Enterococcus faecalis (ATCC 22735) were obtained from the Department of Biotechnology, Vaal University of Technology, South Africa. Stock culture was maintained at $4^{\circ} \mathrm{C}$ on slants of nutrient agar. The active stock culture was inoculated 
in fresh tubes of Muller-Hinton Broth Medium (MHB) and the bacteria were incubated for $24 \mathrm{~h}$ at $37^{\circ} \mathrm{C}$.

\section{Screening for the Antimicrobial Potential of the fractions}

The bacteria cultures were grown in nutrient broth liquid medium at $37^{\circ} \mathrm{C}$. After $24 \mathrm{~h}$ of growth, each microorganism, at a concentration of $10^{6}$ cells $/ \mathrm{mL}$, was inoculated on the surface of nutrient broth plates. A $6 \mathrm{~mm}$ in diameter disk impregnated with $1000 \mu \mathrm{g} / \mathrm{ml}$ of the fractions was placed on the surface of the inoculated Petrie dish and incubated at $37^{\circ} \mathrm{C}$ for $24 \mathrm{~h}$. The Zones Of Inhibition (ZI) were measured after $24 \mathrm{hrs}$ and fractions with ZI more than $7 \mathrm{~mm}$ were reported as being sensitive [19]. In this study, the $2 \%$ DMSO and Tween 80 were used to dissolve the fractions in the culture media and were used as the negative control. And they showed no inhibitions in this study. These tests were performed in triplicate.

\section{Determination of the Minimum Inhibitory Concentration (MIC)}

The fractions with ZI more than $7 \mathrm{~mm}$ were subjected to further antimicrobial assay to determine theMinimal Inhibitory Concentration. Serial dilution of the active fractions of concentrations about $12.5-50 \mu \mathrm{g} / \mathrm{ml}$ were prepared and was used to impregnate the disk overnight. The impregnated disk was placed on the inoculated plates and incubated overnight at $37^{\circ} \mathrm{C}$. After $24 \mathrm{hrs}$, the MIC of each fraction and ampicillin sodium salt (positive control) was determined [20]. These tests were performed in triplicate.

\section{Antioxidant Assay}

\section{DPPH assay}

The antioxidant activity of the fractions was examined on the basis of the scavenging effect on the stable 2,2-diphenyl-1picrylhydrazyl (DPPH) free radical [21]. Freshly prepared $300 \mu \mathrm{l}$ of $0.05 \mathrm{mM}$ ethanolic solution of DPPH was added to $40 \mu \mathrm{l}$ of each fraction with concentrations of $0.02-2 \mathrm{mg} / \mathrm{ml}$. To the mixture, $2.7 \mathrm{ml}$ of $96 \%$ ethanol was added and vortexed vigorously. The mixture was left incubate for 5 mins at ambient temperature and absorbance measured spectrophotometrically at $517 \mathrm{~nm}$. A blank sample was prepared and all determinations were performed in triplicate. The radical scavenging activities of the tested fractions expressed as a percentage of inhibition were calculated according to the following equation [21].

Present $(\%)$ Inhibition of DPPH Activity $=[(A B-A A) / A B] \times 100$

Where $A_{A}$ and $A_{B}$ are the absorbance values of the test and of the blank, respectively. A percent inhibition versus concentration curve was plotted and the concentration of fractions required for $50 \%$ inhibition was determined and represented as $\operatorname{LD}_{50}(\mu \mathrm{M})$ for each of the test solutions. All determinations were carried out in triplicate.

\section{ABTS assay}

Experiments were performed according to Re, Pellegrini, Proteggente, Pannala, Yang, Rice-Evans [22], with small modifications. ABTS of $7 \mathrm{mM}$ and potassium persul $\neg$ fate of 2.45 $\mathrm{mM}$ were prepared in distilled water and these two solutions mixed. The mixture was allowed to stand in the dark at ambient temperature for $16 \mathrm{hrs}$ to generate the ABTS radical (ABTS•+). The ABTS radical solution was diluted with distilled $\mathrm{H} 2 \mathrm{O}$ to an absorbance of 1.00 at $734 \mathrm{~nm}$ and the fractions of concentrations $0.02-2 \mathrm{mg} / \mathrm{mL}$ were added to diluted ABTS $\bullet+$ solution and the absorbance reading was taken after 6 min of incubation at 734 $\mathrm{nm}$. Results are presented as the ability of extract to scavenge 50 $\%$ of free radical ABTS $\bullet+($ IC50). All determinations were carried out in triplicate. Ascorbic acid was used as a positive control.

\section{Results And Discussion}

\section{Influence of Solvent On The Recovery Yield of Secondary Metabolite}

Table 1: Nature of the Secondary Metabolite from the A. decurrens Stem Bark.

\begin{tabular}{|c|c|c|}
\hline Menstruum & Nature & Colour \\
\hline Hexane & Oily & Lemon \\
\hline Chloroform & Solid & Light brass gold \\
\hline Ethyl acetate & Solid & Dark brown \\
\hline Methanol & Solid & Chocolate \\
\hline
\end{tabular}

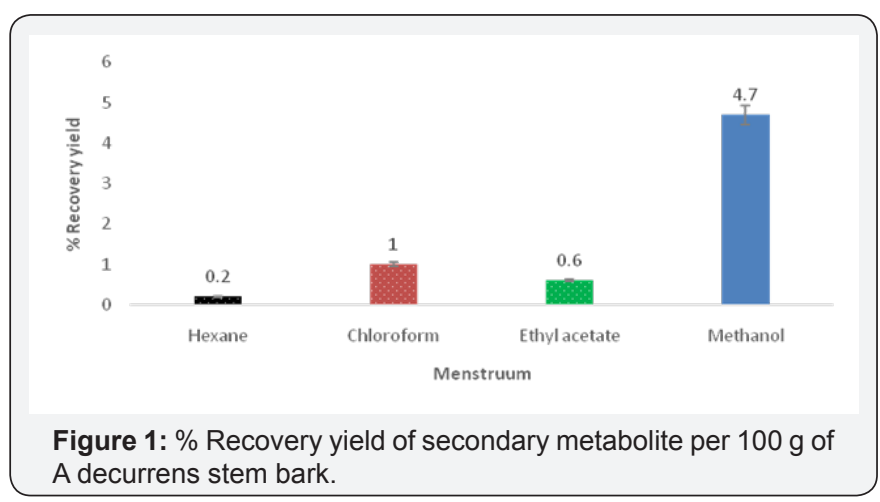

The fractions obtained from the four solvent extractions were different in colours and nature (Table 1). The methanol fraction gave the greatest yield (20\%), whereas the hexane fraction had the lowest yield ( $0.2 \%$ ) (Figure 1 ) and there was a significant difference in extraction yield between the methanol and the other fractions. This implies that most of the secondary metabolite is highly polar. These results are consistent with the previous studies of materials, which reported that extraction solvents significantly affect the recovery yields of a secondary metabolite from the plant (Table 1).

According to some researchers, aqueous, methanol and ethanol have been proven as effective solvents to extract phytochemical compounds from different plants [23]. The differences in the dielectric constants and polarities of the solvents used, result in different extraction yields of the secondary metabolite. These findings further confirm that extraction solvent plays an important role in extractability of secondary metabolite from the materials and each material has a more suitable solvent for extraction of secondary metabolite [24] (Figure 1). 


\section{Organic and Medicinal Chemistry International Journal}

\section{Preliminary Phytochemical Screening}

Table 2: Qualitative Phytochemical Screening.

\begin{tabular}{|c|c|c|c|c|}
\hline Phytochemical & $\begin{array}{c}\text { Hexane } \\
\text { Fraction }\end{array}$ & $\begin{array}{c}\text { Chloroform } \\
\text { Fraction }\end{array}$ & $\begin{array}{c}\text { Ethyl } \\
\text { Acetate } \\
\text { Fraction }\end{array}$ & $\begin{array}{c}\text { Methanol } \\
\text { Fraction }\end{array}$ \\
\hline Alkaloids & + & ++ & NA & NA \\
\hline Glycosides & + & +++ & +++ & +++ \\
\hline Phenols & NA & +++ & +++ & ++ \\
\hline Saponins & NA & NA & NA & +++ \\
\hline Terpenoids & +++ & ++ & +++ & +++ \\
\hline Tannins & ++ & +++ & +++ & +++ \\
\hline Flavonoids & NA & NA & +++ & +++ \\
\hline \multicolumn{7}{|c|}{ NA, absent; +, low in abundance; ++, moderate in abundance; +++} \\
\hline
\end{tabular}

The results provide evidence of the presence of terpenoids, phenols, tannins, flavonoids, saponins, alkaloids in various fractions of $A$. decurrens stem bark. The major outcome of the present investigation revealed that the samples tested contained high concentrations of health-enhancing phytochemical constituents which are an indication that the plant has a medicinal value other than the tree being grown for firewood, or as a fast-growing windbreak or shelter tree [25] (Table 2).

NA, absent; +, low in abundance; ++, moderate in abundance; +++ , high in abundance

The compounds identified in the fractions include steroids and tannins, which are known to mediate cardiotonic (Table 2) and possesses insecticidal, antioxidant, antimicrobial activities [26], phenols and flavonoids which may possess antioxidative, antidiabetic, anticarcinogenic, antimicrobial, antiallergic, antiinflammatory and antimutagenic activities [26-27] Ghani A [28] reported that ethnomedicinally the stem bark is being used for the treatment of diarrhoea and as an astringent.

\section{Quantitative Phytochemical Screening}

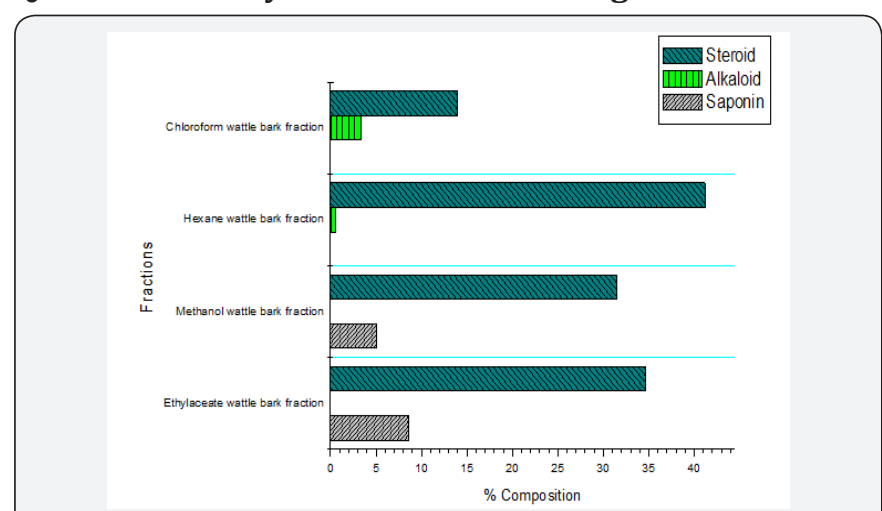

Figure 2: \% composition of principle in various Acacia decurrens fractions.

The alkaloids were present in the hexane and chloroform (0.6 - 3.3) \%, steroids in hexane, chloroform, ethyl acetate and methanol (13.92 - 41.2) \% and saponins in ethyl acetate and methanol (5.1 - 8.6) \% (Figure 2). Alkaloids, saponins, and steroids have not been implicated as potent antioxidant compounds because of their mechanism of action while phytochemical compounds like phenols, flavonoids, and tannins have been greatly implicated as potent antioxidant compounds [29] (Figure 2).

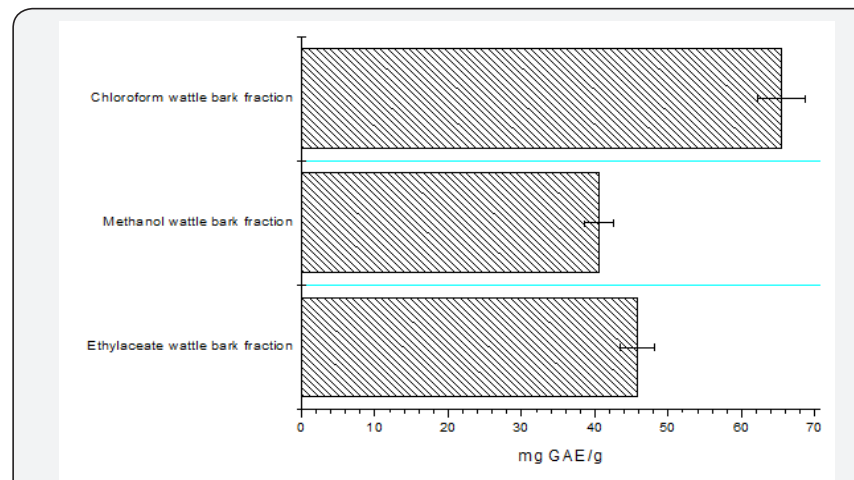

Figure 3: Total phenol (mgGAE/g) content.

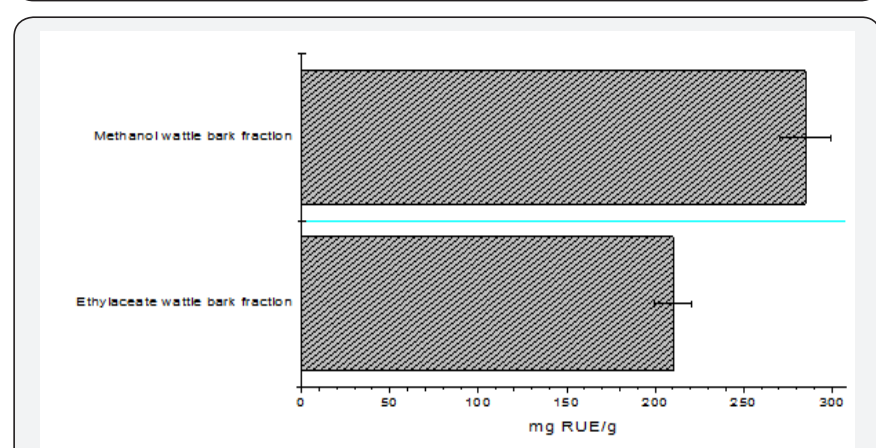

Figure 4: Total flavonoid (mg RUE/g) content.

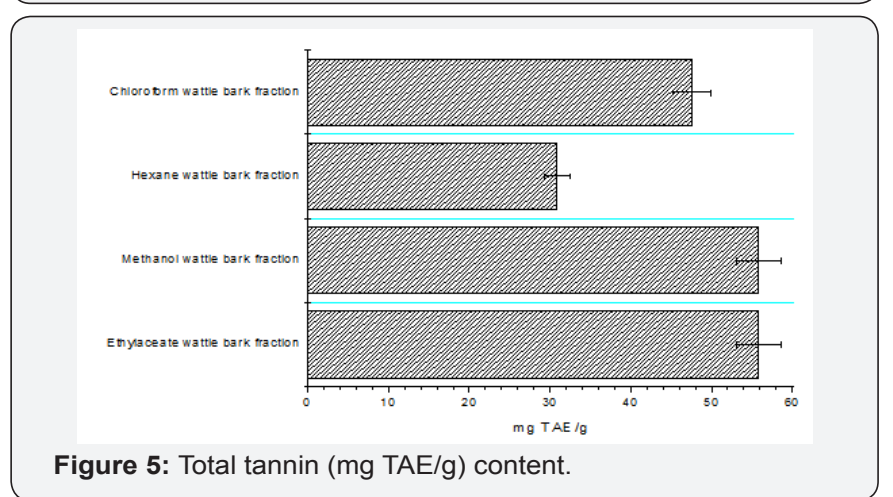

The total phenolic content of the chloroform, ethyl acetate, and methanol, calculated from the calibration curve (R2 = 0.9903 ), ranges from $406 \pm 1.70-655 \pm 0.35 \mathrm{mg} \mathrm{GAE} / \mathrm{g}$ (Figure 3 ), total flavonoid content of the ethyl acetate and methanol (R2 $=0.9986$ ) were $210.24 \pm 2.20-284.92 \pm 1.02 \mathrm{mg}$ RUE/g (Figure 4) and total tannin content of the hexane, chloroform, ethyl acetate and methanol of $A$. decurrens stem bark fractions (R2 = 0.9921 ) were $30.87 \pm 1.73-55.80 \pm 2.00 \mathrm{mg} \mathrm{TAE} / \mathrm{g}$ (Figure 5). Phenolic compounds have redox properties, which allow them to act as antioxidants [30]. There is a significant rise in the amount of tannin and flavonoids extracted as the polarity of the solvent changes from hexane, chloroform, ethyl acetate to methanol because tannins are water soluble polyphenol compounds [31] and flavonoids are composed of a simple skeleton containing 


\section{Organic and Medicinal Chemistry International Journal}

two phenol rings connected by a propionic chain [32]. The hypertolerance for heavy metals by the plant is justified by a lot of secondary metabolites with chelating potentials which the lone pairs of an electron can be deposited in the empty d-orbitals, keep the metals in an inactive state (Figures 3-5).

\section{UV-visible absorption of the A. decurrens fractions}

The fractions have similar absorption maxima with the hexane and ethyl acetate fractions having an additional absorption maximum in the visible region at $410(0.116)$ and in the UV region $390(0.648)$ and $345(0.663) \mathrm{nm}$ respectively. There is a remarkable difference in the absorption pattern of the methanol fraction compared to the other fractions indicating a different structural feature of its compositional compounds, as confirmed in the report of Masayoshi [33], that there is a close relationship between the absorption of the organic compound and its structure. The three absorption maxima of the methanol fraction are all in the UV region, which is an indication of the absence of extensively conjugated compounds. The UV-visible absorption results are in conformity with the qualitative phytochemical screening (Table 2) result, with similar secondary metabolites present.

\section{Elemental composition of A. decurrens stems bark}

The concentration of nine metals were analysed using PerkinElmer Elan DRC II inductively coupled plasma mass Altec
Mercury Analyzer AMA 254 and the elemental concentrations are presented in Figure 6. The stem bark was found to have high concentrations of heavy metals such as $\mathrm{Co}, \mathrm{Zn}, \mathrm{Mn}, \mathrm{Fe}, \mathrm{Ni}$ and $\mathrm{Cr}$ due to bioaccumulation. This is an indication that the plant has a high phyto- tolerance capacity and can be employed for green remediation [34] (Figure 6). The hyper-accumulation capacity for heavy metals due to $A$. decurrenshyper-tolerance, or phytol tolerance potential; explains the adaptive evolution of A. decurrens to hostile environments through many generations which have earned its invasive classification in South Africa [4]. The sorption potential is high and will have an adverse effect on native wildlife and vegetation but can be exploited as a source of controlled green-herbicide.

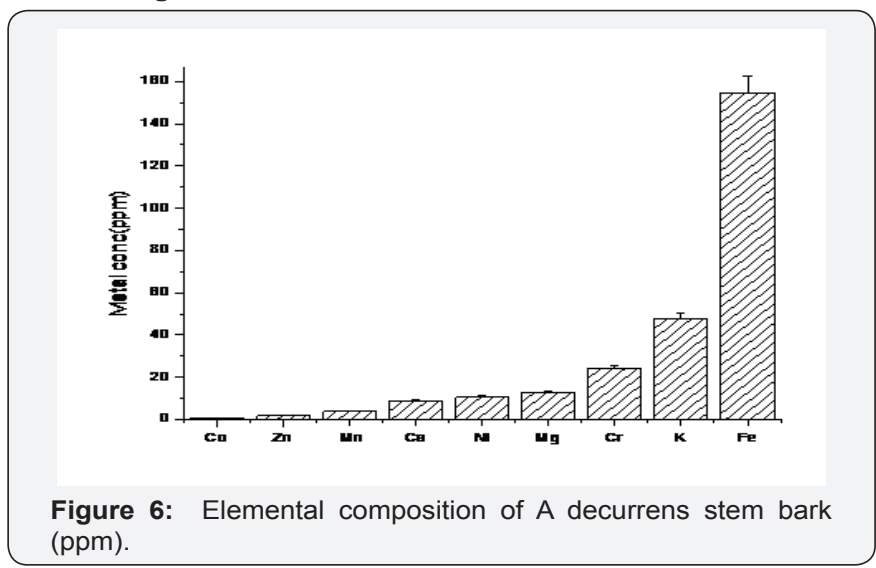

\section{GC-MS analysis of the A. decurrens fractions}

Table 3: Profile of the Eluted Compounds Presented as Retention Time (min).

\begin{tabular}{|c|c|c|c|c|c|c|}
\hline \multirow[b]{2}{*}{ Compounds } & \multicolumn{6}{|c|}{ Retention Time (min) } \\
\hline & Hexane Fraction & $\mathbf{m} / \mathbf{z}$ & $\begin{array}{l}\text { Chloroform } \\
\text { Fraction }\end{array}$ & $\mathbf{m} / \mathbf{z}$ & $\begin{array}{l}\text { Ethyl Acetate } \\
\text { Fraction }\end{array}$ & $\mathbf{m} / \mathbf{z}$ \\
\hline 1 & 3.22 & 142 & 3.76 & 388 & 4.19 & 264 \\
\hline 2 & 10.78 & 182 & 7.18 & 142 & 6.47 & 318 \\
\hline 3 & 11.3 & 298 & 8.75 & 199 & 9.09 & 328 \\
\hline 4 & 12.26 & 387 & 9.44 & 207 & 9.39 & 341 \\
\hline 5 & 12.59 & 374 & 11.16 & 222 & 11.22 & 350 \\
\hline 6 & 13.99 & 328 & 16.01 & 218 & 12.44 & 378 \\
\hline 7 & 20.07 & 370 & 19.43 & 290 & 19.73 & 320 \\
\hline 8 & 21.25 & 253 & 20.59 & 308 & 21.57 & 396 \\
\hline 9 & & & 23.01 & 327 & 25.39 & 252 \\
\hline 10 & & & 24.21 & 347 & 26.45 & 232 \\
\hline 11 & & & 25.05 & 371 & 27.4 & 326 \\
\hline 12 & & & 26.79 & 295 & 28.53 & 347 \\
\hline 13 & & & 29.19 & 260 & 29.11 & 247 \\
\hline 14 & & & 29.81 & 265 & & \\
\hline
\end{tabular}

The GC-MS analysis of the stem bark clearly stems bark shows the presence of fifty-two major compounds in the hexane, chloroform, and ethyl acetate fractions in which most of the other compounds are presence in less than $20 \%$ composition of the fractions. The hexane, chloroform and ethyl acetate fractions contain eight, fourteen thirteen majort compounds respectively with retention time and $\mathrm{m} / \mathrm{z}$ values presented in Table 3 . The hexane and ethyl acetate fractions showed similar absorption maxima in the visible region at $410(0.116)$ and in the UV region $390(0.648)$ and $345(0.663) \mathrm{nm}$ respectively due to the presence of possible chromophores on the major compounds in the hexane and $\mathrm{f}$ ethyl acetate fractions. There is also a remarkable 


\section{Organic and Medicinal Chemistry International Journal}

similarity in the free radical scavenging activities of the hexane, similarity of the secondary metabolites but with different IC50 chloroform, and ethyl acetate fractions due to the structural because of some distinct compounds present (Table 3).

\section{Evaluation of the antimicrobial potential of plant fractions}

Table 4: Sensitivity of the fractions against the test organisms.

\begin{tabular}{|c|c|c|c|c|c|}
\hline Bacteria & Hexane Fraction & Chloroform Fraction & $\begin{array}{l}\text { Ethyl Acetate } \\
\text { Fraction }\end{array}$ & Methanol Fraction & Ampicillin \\
\hline Staphylococcus aureus & + & - & + & + & + \\
\hline Eschoriahia coli & - & - & - & - & - \\
\hline Salmonella typhi & + & - & + & - & + \\
\hline Kebsiella pneumoniae & - & - & - & - & - \\
\hline Micrococcus luteus & + & + & + & + & + \\
\hline Shigella sonnei & - & - & + & + & + \\
\hline $\begin{array}{c}\text { Staphylococcus } \\
\text { epidermis }\end{array}$ & - & - & + & + & + \\
\hline $\begin{array}{c}\text { Listeria } \\
\text { monocytogenes }\end{array}$ & - & - & + & + & + \\
\hline Enterococcus faecalis & - & + & + & + & + \\
\hline
\end{tabular}

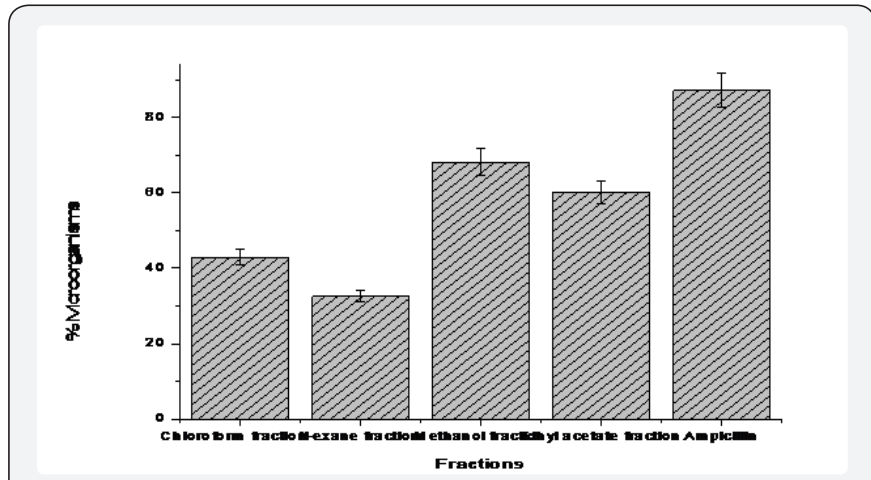

Figure 7: Antibacterial activity from plant fractions against susceptible test microorganism.

The data pertaining to the antimicrobial potential of the plant fractions are presented in Table 4 and Table 5. All the fractions from $A$. decurrens presented antimicrobial activity to at least one of the tested microorganisms with the fractions from ethyl acetate and methanol presenting the highest activities, i.e., they were able to inhibit (60.3\%) and (68.2\%) tested of microorganisms of interest respectively. On the other hand, the hexane and chloroform fractions from $A$. decurrens did show less than $50 \%$ anti-bacterial activity (Figure 7). All the fractions

\begin{tabular}{|c|c|c|c|c|c|}
\hline Bacteria & Hexane Fraction & Chloroform Fraction & Ethyl Acetate Fraction & Methanol Fraction & Ampicillin \\
\hline Staphylococcus aureus & & & 12.5 & 12.5 & 12.5 \\
\hline Eschoriahia coli & 50 & & & 12.5 & 12.5 \\
\hline Salmonella typhi & 50 & & 12.5 & 12.5 & 12.5 \\
\hline Kebsiella pneumoniae & & & 12.5 & 12.5 & 12.5 \\
\hline Micrococcus luteus & 25 & 50 & 12.5 & 12.5 & 12.5 \\
\hline Shigella sonnei & & & & 12.5 & 12.5 \\
\hline Staphylococcus epidermis & & & & & 12.5 \\
\hline Listeria monocytogenes & & & & & \\
\hline Enterococcus faecalis & & & & & \\
\hline
\end{tabular}

tested and ampicillin was active against all the organisms expect for $E$ coli and $K$ pneumonia. Such results were not totally unexpected since these bacteria form resistance to penicillin is mediated by penicillinase, rendering the antibiotic ineffective (Table 4).

Among the fractions, the ethyl acetate fraction showed the highest antimicrobial activity comparable to the control. However, no activity against resistant bacteria likes $E$ coli and K pneumonia due to the absence of potent compounds against or due to the presence of resistance genes in plasmids of the organism [35]. On the other hand, $E$ faecalis, $S$ aureus, $S$ sonnei, $S$ epidermis and $L$ monocytogenes which are also resistant to different antibiotics, had their growth inhibited by the ethyl acetate and methanol fractions. M luteus was observed to have shown susceptibility all the fractions despite the fact that M luteus survive in oligotrophic environments for extended periods of time [36] (Figure 7), the sensitivity is an indication that the extracts contain potent compound for the treatment of opportunistic infection caused by $M$ luteus such as recurrent bacteremia, septic shock, septic arthritis, endocarditis, meningitis, intracranial suppuration, and cavitating pneumonia in immunosuppressed patients.

Table 5: Antibacterial screening $(\mu \mathrm{g} / \mathrm{ml})$ of the isolated compound on test microorganisms. 


\section{Organic and Medicinal Chemistry International Journal}

The data obtained, through the determination of MIC, shows that the polar fractions of the extract contain potent antibacterial compounds (Table 5). The ethyl acetate and methanol fractions showed anti-bacteria activity towards the same set of tested organism (Table 4) with MIC of $12.5 \mu \mathrm{g} / \mathrm{ml}$. This observed MIC for the polar fractions is comparable with the MIC of ampicillin, this is an indication that the polar extracts act as an irreversible inhibitor of the enzyme transpeptidase, which is needed by bacteria to make the cell wall just like ampicillin [37] (Figure 7). The two critical stages of bacterial cell wall production in binary fission is usually breached by Ampicillin ultimately leading to cell lysis; therefore, ampicillin, ethyl acetate, and methanol fractions can be referred to as being bacteriolytic [37]. The hexane and chloroform fractions show very low and similar activity MIC with the hexane fraction being more potent against $E$ coli, $S$ typhi and M luteus with MIC of $25-505 \mu \mathrm{g} / \mathrm{ml}$. The similarity in activity can be justified by the presence of closely related compounds as indicated in the GC-MS result.

\section{Antioxidant Assay}

The fractions exhibited moderate radical scavenging activity. The hexane fraction and chloroform fractions showed comparative antioxidant activities and are more potent when compared with the radical scavenging activities of the ethyl acetate and methanol fractions. The radical scavenging potential in the form of their IC $_{50}$ values revealed that ascorbic acid (IC50 $=31.7 \mathrm{mg} / \mathrm{mL}$ ) $>$ chloroform fraction $\left(\mathrm{IC}_{50}=37.8 \mathrm{mg} / \mathrm{mL}\right.$ ) > ethyl acetate fraction $\left(\mathrm{IC}_{50}=46 \mathrm{mg} / \mathrm{mL}\right)>$ methanol fraction $>\left(\mathrm{IC}_{50}=\right.$ $48.6 \mathrm{mg} / \mathrm{mL}$ ) > hexane fraction $\left(\mathrm{IC}_{50}=75 \mathrm{mg} / \mathrm{mL}\right.$ ). Similar results were observed using ABTS analysis, the radical scavenging decreases in the order chloroform fraction $\left(\mathrm{IC}_{50}=42.2 \mathrm{mg} / \mathrm{mL}\right.$ ) $>$ methanol fraction $\left(\mathrm{IC}_{50}=44.6 \mathrm{mg} / \mathrm{mL}\right)>$ ethyl acetate fraction $\left(\mathrm{IC}_{50}=49.6 \mathrm{mg} / \mathrm{mL}\right)>$ ascorbic acid $\left(\mathrm{IC}_{50}=54.7 \mathrm{mg} / \mathrm{mL}\right)>$ hexane fraction $\left(\mathrm{IC}_{50}=54.7 \mathrm{mg} / \mathrm{mL}\right.$ (Figure 8).

Ascorbic acid standard acts as a chain breaking the free radical chains [38-39]. The scavenging activity observed for the different fractions is a function of the secondary metabolites present and their hydrogen-donating ability which reduces the blue-green ABTS* and purple DPPH *coloured solutions. The phytochemical screening showed that the chloroform fraction with $\mathrm{IC}_{50} 37 \mathrm{mg} / \mathrm{mL}$ against the $\mathrm{DPPH}^{*}$ and $\mathrm{IC}_{50} 42.2 \mathrm{mg} / \mathrm{mL}$ against the ABST* is the most potent due to the relatively high phenolic (65.5 mg GAE/g) and tannin (47.5 mg TAE/g) contents, which is in agreement with the work of RE Beyer [38], which reported direct correlation between the phenolic and tannin contents to the antioxidant activity.

The ethyl acetate and methanol fractions were potent antioxidant compounds with relative good IC $_{50}$ due to the presence of flavonoids, phenols and tannins, while the antioxidants activity of the hexane fraction with $\mathrm{IC}_{50} 75 \mathrm{mg} / \mathrm{mL}$ against the $\mathrm{DPPH}^{*}$ and $\mathrm{IC}_{50} 57.8 \mathrm{mg} / \mathrm{mL}$ against the $\mathrm{ABST}^{*}$ is the least potent due to the absence principle antioxidant metabolites (Figure 8) [39]. The $A$. decurrens stem bark extracts showed higher antioxidant activity with DPPH when compared to ABTS, with more potent activity than the positive control (ascorbic acid) in the ABTS assay, Brand-Williams, et al. [40] reported similar slow reaction of most antioxidants which were tested with the ABTS. The phytochemical screening of the chloroform fraction indicates the presence of phenols and GC-MS spectrum with fourteen distinct compounds from the hexane fraction which are most likely phenols. This distinct set of compounds has greatly impacted on the antioxidant activity of the chloroform fraction, as the free radical scavenging ability is facilitated by their hydroxyl groups.

Flavonoids, including flavones, flavonols, and condensed tannins, are plant secondary metabolites present in the ethyl acetate and methanol fractions owe their antioxidant activities to the presence of free $\mathrm{OH}$ groups, especially $3-\mathrm{OH}$ hence, the trend of scavenging activity observed in the extracts. Flavonoids have antioxidant activity in vitro and also act as antioxidants in vivo depending onto the presence of free $\mathrm{OH}$ groups, especially $3-\mathrm{OH}$ $[41,42]$. A lot of phenols and flavonoids justify the comparative scavenging potential of the extracts and not necessarily a number of flavonoids alone.

\section{Conclusion}

The findings from this study confirm chloroform as the most effective solvent for extracting potent antioxidant compounds while the ethyl acetate and methanol as the most effective solvent for extracting potent anti-bacteria compounds. The phytochemical constituent presence in the chloroform fraction were sterols, flavonoids, alkaloids, tannins and phenols which are known to exhibit antioxidant activity while the ethyl acetate and methanol were discovered to contain terpenoids, phenols, tannins, flavonoids, saponins, glycosides. The GC-MS of the hexane, chloroform, and ethyl acetate extracts confirms the presence of fifty-two compounds with the methanol fraction excluded due to the poor peak resolution as a result of the large quantity of polar biologically active phytochemical substances.

Plant ethyl acetate and methanol fractions have great potential as antimicrobial compounds against the tested microorganisms with MIC of $12.5 \mu \mathrm{g} / \mathrm{ml}$. Thus, they can be used in the treatment of infectious diseases caused by resistant microbes. The efficiency of antioxidants in chloroform, ethyl acetate, and methanol fractions, studied using ABTS and DPPH radical scavenging assay, indicated that the $\mathrm{IC}_{50}$ for chloroform and the other fractions is dependent on the quantity of phenolic, tannins and the presence of free $\mathrm{OH}$ groups, especially $3-\mathrm{OH}$ compounds present in the flavonoids. The free radical scavenging activity in the chloroform fraction is comparatively stronger than other fractions. This is the first report on the antioxidant activity and the hyperaccumulator capacity for heavy metals by A. decurrens.

\section{Acknowledgement}

We are thankful to Directorate of research, Vaal University of Technology, Vanderbijlpark, Gauteng, South Africa, for providing all necessary facilities to conduct the experiment. 


\section{Organic and Medicinal Chemistry International Journal}

\section{Conflict of Interest Statement}

We declare that we have no conflict of interest.

\section{References}

1. Quattrocchi (2012) CRC World Dictionary of Medicinal and Poisonous Plants: Common Names, Scientific Names, Eponyms, Synonyms, and Etymology. CRC Press 5: p.2185.

2. BJ Hutton (1866) Plants of the Bible. 2017.

3. WR Elliot, DL Jones (2002) Encyclopaedia of Australian plants suitable for cultivation. Encyclopaedia of Australian Plants.

4. NAF Miranda, JB Adams (2011) Alien and invasive species. Ecology and Conservation of Estuarine Ecosystems: Lake St Lucia as a Global Model. p. 367-380.

5. RD Wallace, CT Bargeron (2014) Identifying invasive species in real time: Early detection and distribution mapping system (EDDMapS) and other mapping tools, in Invasive Species and Global Climate Change. pp. 219-231.

6. IS Young, JV Woodside (2001) Antioxidants in health and disease Antioxidants in health and disease. J Clin Pathol 54(3): 176-186.

7. B Halliwell (1994) Free radicals, antioxidants, and human disease: Curiosity, cause, or consequence? Lancet 344(8924): 721-724.

8. F Pourmorad, SJ Hosseinimehr, N Shahabimajd (2006) Antioxidant activity, phenol and flavonoid contents of some selected Iranian medicinal plants. African J Biotechnol 5(11): 1142-1145.

9. G Cao, E Sofic, RL Prior (1996) Antioxidant capacity of tea and common vegetables. J Agric Food Chem 44(11): 3426-3431.

10.JB Harborne (1998) Phytochemical Methods; A Guide to Modern Techniques of Plant Analysis. Chapman and Hall 3: 317.

11. M Nibedita, P Taranisen, S Shantilata (2015) International Journal of Herbal Medicine. Int J Herb Med 32015(2): 24-33.

12.J Zhishen, $T$ Mengcheng, $W$ Jianming (1999) The determination of flavonoid contents in mulberry and their scavenging effects on superoxide radicals. Food Chemistry 64(4): 555-559.

13. R Singh (2012) Total phenolic, flavonoids and tannin contents in different extracts of Artemisia absinthium. J Intercult Ethnopharmacol 1(2): 101-104.

14. S Fazel, M Hamidreza, G Rouhollah, M Verdian-Rizi (2010) Spectrophotometric determination of total alkaloids in some Iranian medicinal plants. J Appl Hortic 12(1): 69-70.

15. HP Makkar, P Siddhuraju, K Becker (2007) Methods in molecular biology: Plant Secondary Metabolites. 393: 1-122.

16. DH Tejavathi, DR Jayashree (2013) Phytochemical Screening of Selected Medicinal Herbs Inoculated With Arbuscular Mycorrhizal Fungi. Ijbpas 2(211): 2090-2106.

17. DO Ogoyi, CJ Mwita, EK Nguu, PM Shiundu (2011) Determination of Heavy Metal Content in Water, Sediment and Microalgae from Lake Victoria, East Africa. Open Environ Eng J (4): 156-161.

18. TD Martin, CA Brockhoff, JT Creed A (1994) Determination of Metals and Trace Metals in Water and Wastes by Inductively Coupled PlasmaAtomic Emission Spectrometry. Usepa 4: 1-58.

19. JM Willey, LM Sherwood, CJ Woolverton (2008) Prescott, Harley and Klein's Microbiology. McGraw-Hill Companies, Inc 1-1088.

20. GGF Nascimento, J Locatelli, PC Freitas, GL Silva (2000) Antibacterial activity of plant extracts and phytochemicals on antibiotic-resistant bacteria. Brazilian J Microbiol 31(4): 247-256.

21. P Veeru, MP Kishor, M Meenakshi (2009) Screening of medicinal plant extracts for antioxidant activity. Life Sci 73(2):167-79.
22. R Re, N Pellegrini, A Proteggente, A Pannala, M Yang, et al. (1999) Antioxidant activity applying an improved ABTS radical cation decolorization assay. Free Radic Biol Med 26 (9-10): 1231-1237.

23. T Dhanani, S Shah, NA Gajbhiye, S Kumar (2017) Effect of extraction methods on yield, phytochemical constituents and antioxidant activity of Withania somnifera. Arab J Chem 10: S1193-S1199.

24. A Ghasemzadeh, HZE Jaafar, A Rahmat, PEM Wahab, MRA Halim, et al. (2010) Effect of different light intensities on total phenolics and flavonoids synthesis and anti-oxidant activities in young ginger varieties (Zingiber officinale Roscoe). Int J Mol Sci 11(10): 3885-3897.

25. R Harris (2003) Trease and Evans pharmacognosy. Int J Aromather 13(1): p. 5.

26. ICW Arts, PCH Hollman (2005) Polyphenols and disease risk in epidemiologic studies. Am J Clin Nutr 81(1): 317S-325S.

27. BK Manjunatha (2006) Antibacterial Activity of Pterocarpus santalinus. Indian J Pharm Sci 68: 115-116.

28. VRJ Oswaldo, JGG Jaime, SL Mónica (2008) Determinación de la calidad ambiental de la ciénaga colombia caucasia antioquia colombia. Gestión y Ambient 10(1): 187-200.

29. IC Chopra, RN Nayar, SL Chopra (1956) Traditional Medicinal Plants Used in the Treatment of Different Skin Diseases of Santals at Abdullahpur Village under Akkelpur Upazilla of Joypurhat District, Bangladesh. Gloss Indian Med 2(1): 17-20.

30. MA Soobrattee, VS Neergheen, A Luximon-Ramma, OI Aruoma, T Bahorun, et al. (2005) Phenolics as potential antioxidant therapeutic agents: Mechanism and actions. Mutat Res 579(1-2): 200-213.

31. VR Soares (2015) Conformação Mecânica : Efeito Da Topografia Na Transferência De Material E No Atrito. Univ Fed (3) p. 102.

32. E Lúcia (2012) Standard Operating Procedures (SOP) for the Spectrophotometric Determination of Phenolic Compounds Contained in Plant Samples.

33. MS Longair (2008) Maxwell and the science of colour. Philos Trans A Math Phys Eng Sci 3(1): 012-016.

34. A Torokk, Z Gulyas, G Szalai, G Kocsy, C Majdik, et al. (2015) Phytoremediation capacity of aquatic plants is associated with the degree of phytochelatin polymerization. J Hazard Mater 299: 371-378.

35. CM Hudson, ZW Bent, RJ Meagher, KP Williams (2014) Resistance Determinants and Mobile Genetic Elements of an NDM-1 Encoding Klebsiella pneumoniae Strain. PLoS One 9(6): e99209.

36. CL Greenblatt, J Baum, BY Klein, S Nachshon, V Koltunov, et al. (2004) Micrococcus luteus - Survival in amber. Microb Ecol 48(1): 120-127.

37. Dale W Bratzler, E Patchen Dellinger, Keith M Olsen, Trish M Perl, Paul G, et al. (2013) Clinical Practice Guidelines for Antimicrobial Prophylaxis in Surgery. ASHP Therapeutic Guidelines 14 (1): 600-682.

38. RE Beyer (1994) The role of ascorbate in antioxidant protection of biomembranes: Interaction with vitamin $\mathrm{E}$ and coenzyme Q. J Bioenerg Biomembr 26(4): 349-358.

39. F Aqil, I Ahmad, Z Mehmood (2006) Antioxidant and free radical scavenging properties of twelve traditionally used Indian medicinal plants. Turkish J Biol 30(3): 177-183.

40. WC Brand-Williams, ME Berset (1995) Use of a free radical method to evaluate Antioxidant activity. LWT- Food Sci Technol 28: 25-30.

41. S Geetha, M Sai Ram, SS Mongia, V Singh, G Ilavazhagan, et al. (2003) Evaluation of antioxidant activity of leaf extract of Seabuckthorn (Hippophae rhamnoides L.) on chromium (VI) induced oxidative stress in albino rats. J Ethnopharmacol 87(2-3): 247-51.

42. K Shimoi, S Masuda, B Shen, M Furugori, N Kinae, et al. (1996) Radioprotective effects of antioxidative plant flavonoids in mice. Mutat Res 350(1): 153-161. 
(C) This work is licensed under Creative (c) Commons Attribution 4.0 License BY DOI: 10.19080/OMCIJ.2017.03.555611

\section{Your next submission with Juniper Publishers} will reach you the below assets

- Quality Editorial service

- Swift Peer Review

- Reprints availability

- E-prints Service

- Manuscript Podcast for convenient understanding

- Global attainment for your research

- Manuscript accessibility in different formats ( Pdf, E-pub, Full Text, Audio)

- Unceasing customer service

Track the below URL for one-step submission

https://juniperpublishers.com/online-submission.php 